\title{
Controling and Supervising the Development of Modern Market in Social Justice Perspective (A Case Study in Banyumas Regency)
}

\author{
Denok Kurniasih \& Paulus Israwan Setyoko \\ Department of Public Administration, Faculty of Social and Political Sciences \\ denokkurniasih@yahoo.com
}

\begin{abstract}
Local government has important roles in developing populist economic. The existence of Banyumas Regional Regulation No. 3/2010 about the Management and Supervising of Traditional Markets, Shopping Centres and Modern Stores is a local government's way to preserve the existence of traditional markets. However, modern markets are growing dramatically; therefore it creates imbalance competition with traditional markets. There are many modern market establishment regulations violated not only by the entrepreneurs but also the street level bureaucracy who gives permits to modern market establishment. It indicates the local government's lack of control in modern markets. This article aims at explaining the failure in controlling and supervising modern markets. In social justice perspective, controlling and supervising modern markets effectively can be achieved by creating suitable regulations and at the same time protecting the traditional markets.
\end{abstract}

Keywords : social justice, modern market, controlling and supervising

\section{Introduction}

The development of modern markets or modern stores in many development countries is rapid, and this is the indication of what we call "supermarketization" (Reardon, etal.,2005.). In one side, the existence of modern markets can be an economic driving force but, on the other side, the modern market can be a pressure for conventional/traditional market development (Suryadarma, et al., 2007; Hawkes, 2008; Ho, 2005). Hence, to protect the existence of traditional markets, Banyumas local government formulates the regional regulation No. 3/2010 about the Management and Supervision of Traditional Markets, Shopping Centres and Modern Stores. This policy aims at coping and maintaining the establishment and existence of modern stores and shopping centres so that their existence would not be detrimental to traditional markets and small and medium enterprises (known as Usaha Kecil dan Menengah UKM).

However, it seems that the Banyumas Regulation No. $3 / 2010$ is not implemented well. The research shows that there are 96 modern stores, 17 of which have no establishment operational permit (BPMPP, 2014). The fact is that the violations get no law enforcement from the local government officials, which indicates lack of control from the local bureaucracy in Banyumas. By 2014, only 4 modern stores permits are suspended because of their violations. This paper aimed at describing the motives of Banyumas regional government's failure in controlling and supervising modern market business.

\section{Research Method}

The research method was qualitative descriptive. This method is used in exploring and understanding the meaning from some of individuals or groups of people about social and humanities problems (Creswell, 2010: 4). The informants of this research were the members of modern market control and supervision team, and the entrepreneurs. The analysis used interactive analysis model (Milles and Huberman, 1992). 


\section{Results}

\subsection{The Failure of Controlling and Supervising in Public Sector}

The studies in managerial control and supervision are still appealing (Berland \& Dreveton, 2006; Alterman, 2013). Public or private sectors have concerns about the controlling matter in organization. Private sector concerns on how to achieve organizational performance, while public sector on how to accomplished public accountability value (Mulgan, 2000; Berland \& Dreveton, 2006).

The development of modern market in Banyumas regency is out of control. It is a sign of the failure in implementing policy specifically Banyumas regional policy No. 3/2010. The absence of law enforcement on the violation is the main reason Banyumas government fails to deal with the rapid development of modern stores. Here, the local government should be able to enforce the law as their responsibility to control the policy implementation (Elmore, 1978; Younis \& Davidson, 1990; Winter, 2003). Consequently, traditional markets have no ability to compete with the modern markets. It leads to economical conflicts between the two, especially if their locations are side by side, against the policy requiring that the minimum distance between traditional and modern markets should be about 500 meters. The management and planning of the city is the main mechanism and instrument in controlling modern market development (Henneberry, et al., 2005).

The lack of control to the policy implementation is also indicated by the incapability of Banyumas government officials in anticipating the fast development of modern markets in near future. They seem to act passively and let everything goes, ignoring the violations towards the regulations on the establishment of modern markets. As stated by Neo $\&$ Chen (2007) what the government needs to do is dynamic governance which has the principles of thinking ahead, thinking again and thinking across. These principles are to create policy process which is future-oriented and adaptive to the changes.

The weaknesses in controlling and supervising the development of modern market are caused by lack of knowledge, especially among the local government apparatuses (well known as Satuan Polisi Pamong Praja, Satpol PP), on the modern market permits. As street-level bureaucrats, Satpol PP should be able to understand the content of the policy so that they can do and run controlling functions towards the violations of the policy (Meyers \& Vorsanger, 2003). It is not surprising that Satpol PP acts as "firefighters" because they close the modern markets after receiving complaints from the public. Here, Satpol PP does not do its main duty in controlling and supervising the existence of modern markets. Satpol PP does not implement its authority to control the permission letter (Allen, 1996; Handoko, 2003; Jones \& George, 2014).

\subsection{Controlling and Supervising in Social Justice Perspective}

The research result found that the lack of supervision toward the permits of modern market is caused by the land owner's status. There are many modern markets owned by the local public officials and their families so that Satpol PP is reluctant to enforce the law. Even if they are not the land owners, the local public officials act as the compradors of the modern market permits in Banyumas (Biersteker, 1981). Because of this situation, Satpol PP only acts and enforces the law toward the modern markets owned by common people who have no relation with the local government officials in Banyumas. Here the value of 
social justice is very important to be discussed. In social justice perspective, the government should give equal support to all members of society including the traditional market owners to improve their competitiveness.

All this time, the government tends to prioritize the big investors since there has been political contract between the public officials and investors at election campaigns. Obviously, there is no protection toward the UKM and traditional markets. The role of public officials as capital owners is also a contributing factor of the problem. The power utilization out of their formal authority, procedures, and organization goals is the nature of day to day politics in practices. Here, ethic is a major problem for the officials because the leader as elected officials has ethical responsibility (Gibson, Ivancevich, \& Donnelly, 2006: 510).

Hence the effort in controlling and supervising markets should be in the frame of social justice. Creating social justice means repairing, changing or even loosing the economic structures, politics, social culture and ideology that can cause some groups of people do not get their right (Magnis-Suseno, 2001; Setyoko, 2011). Social justice is a fundamental element in public administration; it is also as moral and ethnic guidance for bureaucracy. More questions arise about the roles of public administration. Here, public administration in practice should fulfill justice and deal with democracy issues, public participation, individual freedom and justice principles (Frederickson, 1982). This argument implies bigger roles and responsibility of the government in creating social justice for the people, including in controlling and supervising modern markets in Banyumas Regency. They must make sure that public interests have been accommodated optimally and the policy process and its result are consistent to democracy values and social justice (Ingraham \& Ban, 1988; Ingraham \& Rosenbloom, 1989). Law enforcement to every single violation should be implemented without seeing the owners' backgrounds. The business people in the region are hopping better government performance in improving the regional economy.

Therefore, the process of obtaining permits and the operationale of modern stores should be controlled well by the bureaucracy. The outputs of the control will create the capability to determine the performance accurately and also to determine the effectiveness and efficiency of organization policy (Jones \& George, 2014: 11).

\section{Conclusions}

The negative impacts of the modern stores development need local bureaucracy's efforts to control and supervise the development, especially to enforce the policy. Low level of commitment of local bureaucracy causes uncontrolled development of modern markets which suppress traditional markets. Sanctions on permit violations should be given equally to all business owners so that there is no impression that the local government officials favor the big investors. Controlling and supervising regulations with justice can be done by limiting the permit of modern markets, changing the policy to protect traditional markets, compliance to the city planning, and empowering the traditional entrepreneurs.

\section{References}

[1].Allen, Richard I.G. (1996). Management Control in Modern Government Administration: An Introduction. SIGMA Papers, OECD Publishing, 4, 10-24. 
[2].Alterman, Rachelle. (2013). Planning Laws, Development Controls and Social Equity: Lessons for Developing Countries. World Bank Law Review, 5.

[3].Berland, Nicolas \& Benjamin Dreveton. (2006). Management Control System in Public Administration: Beyond Rational Myths. Accounting Reform in Public Sector : Mimicry Fad or Necessity (pp.21-37)

[4].Biersteker, Thomas J. (1981). Distortion or Development? Contending Perspectives on the Multinational Corporation. Cambridge, MA: The MIT Press.

[5].Creswell, John W. (2009). Research Design. Qualitative, Quantitative and Mixed Methods Approach, Third Edition, California: Sage Publications.

[6]Elmore, Richard E. (1978). Organizational Models of Social Program Implementation, Public Policy, 26 (2), 185-228.

[7].Frederickson, H.G. (1982). The Recovery of Civism in Public Administration. Public Administration Review, 42, (6), 501 - 509.

[8].Handoko, T.Hani, 2003. Manajemen, Yogyakarta: BPFE.

[9]. Hawkes, C. (2008). Dietary Implications of Supermarket Development: A Global Perspective. Development Policy Review 26(6), 657-692.

[10].Henneberry, J., McGough, T. \&Mouzakis, F. (2005). Estimating The Impact of Planning on Commercial Property Markets. In D. Adams, C. W. Atkins \& M. White (Eds.), Planning, Public Policy and Property Markets. Oxford: Blackwells

[11].Ho, S.C. (2005). Evolution versus Tradition in Marketing Systems: The Hong Kong Foodretailing Experience. Journal of Public Policy and Marketing 24(1), 90-9
[12].Ingraham, P. W. \& Ban, C. (1988). Politics and Merit: Can They Meet in a Public Service Model? Review of Public Personnel Administration, 8 (2), $1-19$.

[13] \&Rosenbloom, D.H. (1989). The

New Public Personnel and the New Public Service. Public Administration Review. 49 (2), $116-125$.

[14] Jones, R. Gareth \& Jenifer M. George. (2014). Contemporary Management. Singapore: McGraw Hill Education.

[15]. Magnis-Suseno, F. (2001). EtikaPolitik: Prinsip-prinsip Moral Dasar Kenegaraan Modern. Jakarta: PT Gramedia Pustaka Utama.

[16] Milles, B Mathew \&Huberman, A Michael, (1992). Analisis Data Kualitatif, Alih Bahasa: Tjetjep Rohaendi. Jakarta: UI Press.

[17] Mulgan R. (2000). Comparing Accountability in the Public and Private Sectors. Australian Journal of Public Administration, 59.

[18] Neo, Boon Siong\& Geraldine Chen. (2007). Dynamic Governance: Embeding Culture Capabilities and Changing in Singapore. Singapore: World Scientific Publishing Co. Pte. Ltd.

[19] Setyoko, Paulus I. (2011). Administrasi Negara dan Kebijakan Publik: Mewujudkan Keadilan Sosial melalui Proses Deliberatif. Pidato Pengukuhan Jabatan Guru Besar Dalam Ilmu Kebijakan Publik. Fakultas Ilmu Sosial dan Ilmu PolitikUniversitasJenderal Soedirman, 27 April 2011

[20] Schipmann, Christin \& Matin Qaim. (2011). Modern Food Retailers and Traditional Markets in Developing Countries: Comparing Quality, Prices, and Competition Strategies in Thailand. 
Applied Economic Perspectives and Policy 33

(3), 345-362.

[21] Suryadarma, D., A. Poesoro, S. Budiyati, \&

A.M. Rosfadhila. (2007). Impact of Supermarkets on Traditional Markets and Retailers in Indonesia's Urban Centers: Research Report. Jakarta: The SMERU Research Institute.

[22] Younis, Talib\& Davidson (eds). (1990). Implementation in Public Policy, Dartmouth Publishing Company Ltd.

[23] Winter, Soren C. (2003). Implementation. InBG Peter and J Pierre (eds.), Handbook of Public Administration. London and Thousand Oaks, CA: Rotledg 